\title{
Bromodomain-Containing Protein 2
}

National Cancer Institute

\section{Source}

National Cancer Institute. Bromodomain-Containing Protein 2. NCI Thesaurus. Code C21376.

Bromodomain-containing protein 2 (801 aa, $\sim 88 \mathrm{kDa}$ ) is encoded by the human BRD2 gene. This protein plays a role in spermatogenesis. 